\title{
Conceptual Framework for Modeling Business Capabilities
}

\author{
J. Brits and G.H.K. Botha \\ Independent Consultants, \\ South Africa
}

\author{
M.E. Herselman, Tshwane \\ University of Technology, \\ South Africa
}

\begin{abstract}
Staying competitive in today's fast changing markets and business environments has become a big issue in organizations these days. To be able to foresee the future of the industry and have insight into customer's articulated and unarticulated needs are critical capabilities that organizations need to acquire in order to stay competitive.

The objective of this research project is to provide a conceptual approach to analyze an organization and to provide a foundation that would support the architecture of an agile organization. Enterprise architecture, business capabilities, organizational analysis and innovation are the main practices that contribute towards the construction of capabilities and the development of the conceptual business capability framework.

The most significant findings from this research study were the development of a conceptual framework that is later utilized to construct business capabilities. A business capability model has also been produced to visually depict a business capability. This study also provided two feedback loops, namely the organizational feedback loop and the innovative feedback loop.
\end{abstract}

Keywords: Business Capabilities, Business Strategy, Innovation, Agile Organization, Information Modeling

\section{Introduction}

The world is currently facing a new era, the fastest-paced era in history. Despite the high unemployment rates currently experienced in many countries, the standard of living has never been as high as today (Simon, 2000) in homes, families, the daily lives of people and especially in organisations. The need for speed, effectiveness and efficiency has become part of the evolution of mankind and has become such an integral part of life that people almost cannot and do not want to live without it.

Material published as part of this publication, either on-line or in print, is copyrighted by the Informing Science Institute. Permission to make digital or paper copy of part or all of these works for personal or classroom use is granted without fee provided that the copies are not made or distributed for profit or commercial advantage AND that copies 1) bear this notice in full and 2) give the full citation on the first page. It is permissible to abstract these works so long as credit is given. To copy in all other cases or to republish or to post on a server or to redistribute to lists requires specific permission and payment of a fee. Contact Publisher@InformingScience.org to request redistribution permission.

This study will focus the effect of this phenomenon on business and organizations and suggests an approach to follow, to illustrate a business's capabilities, in the context of information architectures, in order to stay competitive. The forces that influence organizations and govern companies in their striving for improved competitiveness are often condensed into three factors, labeled the 
three C's: customers, change and competition (Simon, 2000).

Capability represents the identity of a firm as perceived by both employees and customers. Capability is the ability to perform better than competitors, using a set of business attributes that is distinctive and difficult to replicate. Capability is a capacity for a set of resources to interactively perform a stretch task (1000Ventures, 2006). It is further said that organizational capabilities are considered to constitute the fundamental source of sustained competitive advantage (Grant, 1996a, 1996b)

There is a widespread view that existing management theory and practice is inadequate in our rapidly changing world and the emerging new economic order (Bryans \& Smith, 2000; Kelly, 1998). This new economy is characterized by three distinguishing properties: globality; intangibility; and inter-connectivity (Coyle, 1999; Kelly, 1998). Strategy is and will always be part of business. Strategy lays out the plan ahead and provides direction to follow this plan. Wendy Robson (1997) defines strategy as: The pattern of resource allocation decisions made throughout an organisation.

From these statements it is clear that there should be some form of intelligence in business that is strategically projected and concerned with the agile re-composition of resources in fast-changing environments. Many authors have lately focused on hyper-competition, where organizations have to adapt to changes in the competitive landscape in innovative ways. Enterprise architecture has been widely embraced as the route to this desired state:

1. Enable integrated business intelligence

2. Connect strategy to execution

3. Enable flexibility and adaptability, so that business capabilities can keep pace with changes in strategy.

King (1995) suggests that the vision of the organisation should be the basis of the guiding architecture. Malhotra (1996) noted that the vision bridges the gap between where the firm is and where it wants to be, but that no single capability can provide a single sustainable competitive advantage. Porter suggested a similar view in his discussion of "complementarities". He argues that the synergies of various capabilities can not easily be imitated by competitors and thus would provide the basis for a stronger position in the market place (Harrison 1996, Pastore 1995).

Bredemeyer Consulting (2003) stated that enterprise architecture serves as business capabilities architecture. A summary of the characteristics of enterprise architecture is given below:

1. Enterprise architecture recognizes that the organisation is a system, and the crosscutting concerns must be addressed first at the overall system level.

2. It recognizes that one cannot solve every detailed problem at once - one cannot hold complex systems "in your head".

3. Effective ways need to be sought to decompose the problem.

4. Enterprise architecture firstly focuses on business capabilities that support business strategy, and then by delving into the design of those capabilities, forms an effective way to consider people, process and technology together.

The purpose of the article is therefore to model business capabilities based on a strategic direction together with innovative principles in order to adapt to change.

\section{Business Capabilities}

Many people today wonder what exactly a business capability is and why it is so important. Capabilities consist of the following (Pandza, Horsburgh, Gorton, \& Polajnar, 2003): Individual 
skills, tacit forms of knowledge, social relations that are embedded in a firm's: routines, managerial processes, forms of communication and culture.

Makadok (2001) refers to a capability as a special type of a resource whose function improves the productivity of other resources. This implies that resources can represent a cluster of elements that constitute a capability.

Because business capabilities are so closely related to competencies this has ultimately become a strategic issue. Most organizations want to be able to build strategic capabilities. A fundamental question in the field of strategic management is: how do firms create and sustain a competitive advantage (Rumelt, R.P., Schendel, D.E. \& Teece, 1991)? Pandza et al. (2003) in their real options approach to managing resources and capabilities mention that capability development has parallels with the application of the real options heuristic to strategy (Bowman \& Hurry, 1993; Kogut \& Kulatilaka, 2001; Bowman \& Moskowitz, 2001;), whereby a firm's resources, capabilities and knowledge create options for future exploitation.

\section{Enterprise Architecture and Business Capabilities}

An organisation may be viewed from many perspectives as interrelated parts working together to achieve the business purpose. Enterprise architecture provides one solution towards this perspective.

John Zachman is a pioneer in the field of enterprise architecture and has developed a framework for enterprise architecture. In his own words: "The Framework as it applies to Enterprises is simply a logical structure for classifying and organizing the descriptive representations of an Enterprise that are significant to the management of the Enterprise as well as to the development of the Enterprise's systems."

In his framework he identifies six interrogatives (who, what, were, when, how and why) and six perspectives (scope - contextual; business model - conceptual; system model - logical; technology model - physical; detailed representations; functioning enterprise - out of context) which form cells that represent a specific abstraction of the enterprise.

Taking this view of the enterprise provides the architect with various aggregations or cells of the enterprise. These cells make management easier by enabling the architect to see different reusable units of the enterprise and how they interact. Enabling the analyst or architect with this view or reusable units, provides a foundation from where they can react to and change the enterprise to adapt to predictable and unpredictable change.

Businesses have to be able to identify and respond to changes in the competitive landscape. Increasingly, these changes have to do with technology, which underpins innovations not just in products, but in services and value delivery, either directly or through the application of technology in innovative ways (Bredemeyer Consulting, 2003).

Thus, an organisation has to be able to react to these changes in the internal and external environment.

Enterprise architecture has been widely embraced as the route to this desired state because it:

i. Enables integrated business intelligence

ii. Connects strategy to execution

iii. Enables flexibility and adaptability, so that business capabilities can keep pace with changes in strategy (Bredemeyer Consulting, 2003)

Table 1 is a representation of Zachman's Framework for Enterprise architecture. 
Table 1: The Zachman Framework for Enterprise Architecture

(Based upon Zachman \& Sowa, 1992)

\begin{tabular}{|c|c|c|c|c|c|c|}
\hline & Data & Function & Network & People & Time & Motivation \\
\hline Scope & $\begin{array}{l}\text { List of things } \\
\text { important to } \\
\text { the business }\end{array}$ & $\begin{array}{l}\text { List of } \\
\text { processes } \\
\text { the business } \\
\text { performs }\end{array}$ & $\begin{array}{l}\text { List of } \\
\text { locations in which } \\
\text { the business } \\
\text { operates }\end{array}$ & $\begin{array}{l}\text { List of } \\
\text { organizations/agents } \\
\text { important to } \\
\text { the business }\end{array}$ & $\begin{array}{l}\text { List of events } \\
\text { significant to } \\
\text { the business }\end{array}$ & $\begin{array}{l}\text { List of } \\
\text { business } \\
\text { goals/strategy }\end{array}$ \\
\hline $\begin{array}{l}\text { Enterprise } \\
\text { Model }\end{array}$ & $\begin{array}{l}\text { Entity/relation } \\
\text { diagram }\end{array}$ & $\begin{array}{l}\text { Process flow } \\
\text { diagram }\end{array}$ & $\begin{array}{l}\text { Logistics } \\
\text { network }\end{array}$ & $\begin{array}{l}\text { Organization } \\
\text { chart }\end{array}$ & $\begin{array}{l}\text { Master } \\
\text { schedule }\end{array}$ & Business plan \\
\hline $\begin{array}{l}\text { System } \\
\text { Model }\end{array}$ & Data model & $\begin{array}{l}\text { Data flow } \\
\text { diagram }\end{array}$ & $\begin{array}{l}\text { Distributed } \\
\text { system } \\
\text { architecture }\end{array}$ & $\begin{array}{l}\text { Human interface } \\
\text { architecture }\end{array}$ & $\begin{array}{l}\text { Processing } \\
\text { structure }\end{array}$ & $\begin{array}{l}\text { Knowledge } \\
\text { architecture }\end{array}$ \\
\hline $\begin{array}{l}\text { Technology } \\
\text { Model }\end{array}$ & Data design & $\begin{array}{l}\text { Structure } \\
\text { chart }\end{array}$ & $\begin{array}{l}\text { System } \\
\text { architecture }\end{array}$ & $\begin{array}{l}\text { Human/techology } \\
\text { interface }\end{array}$ & $\begin{array}{l}\text { Control } \\
\text { structure }\end{array}$ & $\begin{array}{l}\text { Knowledge } \\
\text { design }\end{array}$ \\
\hline Components & $\begin{array}{l}\text { Data definition } \\
\text { description }\end{array}$ & Program & $\begin{array}{l}\text { Network } \\
\text { architecture }\end{array}$ & $\begin{array}{l}\text { Security } \\
\text { architecture }\end{array}$ & $\begin{array}{l}\text { Timing } \\
\text { definition }\end{array}$ & $\begin{array}{l}\text { Knowledge } \\
\text { definition }\end{array}$ \\
\hline $\begin{array}{l}\text { Functioning } \\
\text { System }\end{array}$ & Data & Function & Network & Organization & Schedule & Strategy \\
\hline
\end{tabular}

The construction of business capabilities is closely related to the cells of Zachman's framework. All of these abstractions of the organisation or cells of the Zachman Framework could be used collectively to compile business capabilities that aim to fulfill organizational goals.

\section{Types of Capabilities}

\section{Functional capabilities}

Functional capabilities deepen functional knowledge (e.g. research and development, manufacturing knowledge and marketing expertise) (Pandza et al., 2003). This functional knowledge is gained through trial and error and experiments. What is very important is that this knowledge should be documented or stored for future reference. This in turn could be used to possibly make the process more effective, efficient and even automated.

\section{Integral capabilities}

Integral capabilities bind together different functional capabilities and also absorb knowledge from external resources and use them productively (Gulati, 1998).

\section{Strategic capabilities}

"A capability is a skill ... that an organisation possesses that enables it to perform activities" (Hubbard, Pocknee \& Taylor, 1997). Most organizations possess a number of basic capabilities. These basic capabilities are those that enable the organizations to run as businesses. Strategic capabilities, above and beyond basic capabilities, have three distinctive characteristics:

i. Of value to the customer (externally focused);

ii. Better than that of the majority of other competitors; and

iii. Difficult to imitate or replicate (Hubbard et al., 1997) 


\section{Dynamic capabilities}

Eisenhardt and Martin (2000) define dynamic capabilities as: organizational routines of strategic nature through which firms obtain new configurations of resources when markets emerge, collide, divide, evolve and die. Prahalad and Hamel (1990) and Leonard-Barton (1995) argue that successful firms are successful because they carefully develop and nurture their competencies.

\section{Capabilities as Knowledge}

Loasby (1998) has conceptualised a capability as a particular kind of knowledge, which is similar to Spender's (1996) view of a capability as collectively held knowledge - and this in turn correlates with the encapsulation of knowledge and resources that this paper would like to present.

Conceptualizing a capability as a system of integrated knowledge and resources leads to acknowledging uncertainty as an intrinsic characteristic of a capability (Pandza et al., 2003). They further argued the point of systems complexity, where the underlying structure is always incomplete, thus indicating a lack of the required knowledge about its systems architecture.

Uncertainty, in other words, is a lack of knowledge, which is usually a result of the dynamic nature of the capability development process. Capabilities fundamentally encapsulate knowledge created and accumulated by the firm (Lei et al., 1996). Prahalad and Hamel (1990) have suggested that a core competence is based on collective learning within the organisation and, consequently, that strategy should be learning-driven.

\section{Innovative Roots of Capabilities}

By now it is quite clear what capabilities are. Innovation complements capabilities, through the generic new product and new business development processes in many aspects because of the following characteristics of capabilities:

i. Emphasis on new knowledge

ii. The element of uncertainty

iii. Teambuilding, involving diverse individuals with varying knowledge and stimulating communication, as important mediator. As Penrose (1959) noted, capabilities depend on team activity in which the knowledge and skills of individuals are transformed into the integrated knowledge of the organisation.

iv. Prototyping. In these disciplines the aim is to project a mental model of the current situation, stimulate group consensus and testing of the generated ideas or concepts (Janszen, 2000).

\section{Analysis and Requirements Gathering}

One of the main purposes of information systems analysis is to collect all relevant information about the universe of discourse of an information system (Pohl, 1993). Very seldom will the internal documents provide the analyst with all the relevant information concerning the business, processes, activities and tasks. Even when these documents are available they sometimes overlook, or do not recognize, the value of certain aspects of the organisation. In this analysis and requirements gathering section information as critical resource will be discussed, together with methods for extracting this critical information, through various information-gathering techniques, namely reading, writing, observation, interviews and questionnaires. These techniques produce the baseline from where the organisation could be modeled and the objects created in the context of the business capability framework. 


\section{Extracting Critical Information}

With the business capability framework insight, the organisation should be analyzed to extract the critical information of the organisation. This information includes:

i. Business entities: Customers, suppliers, invoices etc

ii. Business rules: facts, derivations and definitions

iii. Business processes: corporate, business unit and operational

iv. Strategic artifacts: vision, mission, objectives and goals

Norman (2005) notes that: "There are five fundamental techniques commonly applied by analysts in the requirements capture phase of a project." These techniques are called SQIRO. It is an abbreviation for sample documents, questionnaires, interviews, reading and observation.

\section{Business Rule Analysis}

Business rules as a separate abstraction has been ignored by analysts for quite some time. Ross (1997) comments that traditional Information Systems methodologies have addressed rules poorly, and only relatively late in the system development lifecycle. However, recent developments in business have shed some light on the importance of business rules. For instance, globalization and mergers oblige organizations to conform (or to be able to conform) to international or local affiliates' ways of working (Kardasis \& Loucopoulos, 2005).

Through the organizational analysis, many business rules have been identified, mostly in the form of business policies, business rules and business rule statements. The Business Rules Group supplies definitions of these terms (Business Rules Group, 2000b):

i. Business rule statement: declarative statement of structure or constraint that the business places upon itself or has placed upon it.

ii. Business rule: a statement that defines or constrains some aspect of the business.

iii. Business policy: general statement of direction for an organisation.

After the business rules analysis these business rules should preferably be stored in a business rules repository so that the analyst has an organized rule repository to work with and a powerful tool to adhere to business and system requirements. In the words of Von Halle (2000): "The business rules approach to analysis moves IT closer to continuous requirements that can support the dynamic business environment."

\section{Business Process Analysis}

According to Whitten and Bentley (2001), process modeling is "a technique for organizing and documenting the structure and flow of data through a system's Processes and/or the logic, policies, and procedures to be implemented by a system's Processes." At this stage of the analysis, the various processes identified through the information gathering stage are classified.

The concept of the value chain now comes into play. For a better understanding of the activities through which a firm develops a competitive advantage and creates shareholder value, it is useful to separate the business system into a series of value-generating activities known as the value chain (NetMBA, 2005).

Figure 1 is an illustration of Porter's primary and secondary activities. 
Porter and Miller's Value Chain Model

Secondary Activities

\begin{tabular}{|l|l|l|l|}
\hline \multicolumn{2}{|l|}{ Administration and infrastructure } \\
\hline Human resource management & $\begin{array}{l}\text { Value } \\
\text { added - } \\
\text { cost }= \\
\text { MARGIN }\end{array}$ \\
\hline \begin{tabular}{l} 
Product/technology/development \\
\hline $\begin{array}{l}\text { Procurement } \\
\text { logistics }\end{array}$
\end{tabular} Operations & $\begin{array}{l}\text { Outbound } \\
\text { logistics }\end{array}$ & $\begin{array}{l}\text { Sales and } \\
\text { marketing }\end{array}$ & Services \\
\hline & Primary Activities \\
\hline
\end{tabular}

Figure 1: Porter and Miller's value chain model (The Researcher)

Analyzing the value chain is essential in the development of business capabilities, in the sense that various capabilities could be linked together to serve a purpose or support specific functions in the chain.

\section{Strategic Analysis}

Strategic analysis is probably the most significant part of management's decision-making process. It focuses all of the decisions of the organisation towards a shared vision, a couple of mission statements, goals and objectives. The practice of strategic analysis essentially produces future organizational direction in a systematic way. In Top management strategy, Tregoe and Zimmerman (1980) define strategy as "the framework, which guides those choices that determine the nature and direction of an organisation."

To analyze in order to act strategically there are various points or areas the analyst has to consider. Robson (1997) divided her strategic analysis approach into three sub-analyses, viz. the analysis of the environment, the objectives and values and the organisational resources.

Strategy is applicable in three functional areas of an organisation, namely corporate, business unit and functional or operating strategy (Tutor, 2004).

In the perspective of this study, a business capability will be defined with a strategic component. That strategic component may be part of any of the above functional areas. This would imply that business capabilities could be applied to and/or constructed for any of the functional areas, thus making it cross-functional.

The value chain perspective also fits in well with this view of cross-functionality, for the value chain is effective in the internal and external environment, leveraging internal operations to corporate goals to serving customers and effectively the industry in the external environment.

\section{Vision and mission}

According to BRG (2000a), the vision is a statement about the future state of the enterprise, without regard to how it is to be achieved. The aim of the vision is to put that star on the horizon to- 
wards which the whole organisation works. Business capabilities are also goal- and futureoriented. The vision object, which will be explained later, encapsulates all other objects.

Mission statements make the vision operative and specify what the organisation does on a day-today basis, as described by Thompson, Strickland and Gamble (2005): "A company's mission is defined by the buyer needs it seeks to satisfy, the customer groups and market segments it is endeavoring to serve, and the resources and technologies that it is deploying in trying to please its customers".

The mission statement will then clearly create a competitive advantage when formulated well and achieved through building core competencies.

\section{Competitive advantage}

Mission statements are closely related to core competencies in that they specify the day-to-day operational activities that keep the organisation in a competitive position. Core competencies are key factors or enablers for sustaining and maintaining a competitive advantage.

Pearce and Robinson (2000) agree with Robson, stating that strategic analysis and choice centre around the identification of effective strategies for building a sustainable, competitive advantage that is based on the core competencies and capabilities of the firm.

Before competencies can be built the analyst should do an environmental analysis and determine what the organisation (internal) is capable of and what it should (external) be capable of.

Tregoe and Zimmerman (1980) urge executives to strategic decisions, towards competitive advantage, on a single "driving force" of the business. When a driving force has been selected, core competencies need to be identified and developed to serve this driving force towards attaining competitive advantage.

\section{Core competencies}

Thompson, Strickland and Gamble (2005) define a distinctive competence as a competitively valuable activity that a company performs better than its rivals representing a competitively superior resource. Thompson, Strickland and Gamble (2005) further state that a core competence only becomes the basis for competitive advantage when it rises to the level of a distinctive competence.

The MCC matrix provides some structure, illustrating how the organisation, vision, mission, core competencies and processes complement and each other. The MCC Matrix is based upon (Robson, 1997):

i. The organisation is seen as a tree

ii. Mission and vision feed the tree

iii. Core competencies serve as roots

iv. Processes produce the fruits in terms of projects and products

\section{Strategic Innovation}

Innovation is a very important aspect of the construction of business capabilities, but innovation without strategic intent might not be enough. Strategists and managers need to look into their futures and understand the industry in which they operate as well as the customers they intend to serve. 


\section{Industry foresight}

Industry foresight consists of a deep understanding of the future state of the industry in which an organisation operates. That understanding and vision should be as far as possible into the future and should be shared among the members responsible for creating it.

\section{Customer insight}

Customer insight represents a deep understanding of customer needs and the drivers of customer behavior at a level well beyond what customers are able to articulate themselves (Innovation Point, 2004)

\section{Identifying and Modeling Business Capability Framework Objects}

The aim of the information-gathering phase is to form the information foundation on which the actual work can be based. This will serve as the information foundation of all the strategic, functional, entity, data, business rule, data flow, and process models to be derived and/or created and interconnected in a value chain fashion.

In the process to identify organizational objects and modeling them in a specific context, depending on the technique used, the objects gain significance towards defining business capabilities.

After the analysis phase is complete many objects have been identified. The types of objects derived are:

1. Organizational Entities

2. Strategic Objects

3. Business Rule Objects

4. Business Process Objects

These objects will be used in the construction of business capabilities.

\section{Construction of Business Capabilities}

In this section the method for implementing the conceptual Capability Framework will be proposed. Innovation, strategic management, motivation and business processes are the foundations of the study's approach. Each of these aspects will be discussed and their roles in fulfilling the main research objective analyzed, vis-à-vis the conceptual framework for the modeling of business capabilities.

More broadly speaking, the section aims to construct dynamic capabilities, which are strategically aligned, guided and governed by business rules, constructed and connected by a business processes approach and finally spawned by the verification of existing knowledge; and the testing, generation and exploitation of knowledge through prototypes, experiments and research.

Combining all these aspects establishes the ability to construct a system, which is:

1. Fed with new knowledge through collaboration with suppliers and customers fishing out their requirements and needs;

2. Visible both up-stream and down-stream;

3. Technologically ready and stable to exploit the use of product lifecycle management, customer relation management and advanced planning scheduling used to leverage the capability of analyzing operations of and foreseeing vision into the value chain; 
4. Flexible and thus able to shift its abilities to fit changing environments and uncertain conditions through easy modifications to products or services to exploit new opportunities.

To construct this system the following is used the seven New Product and New Business Development processes and the Conceptual Framework for modeling business capabilities.

\section{The seven new product and new business development processes}

New product development and new business development can best be characterized as very ambiguous processes full of uncertainties. These uncertainties are diminished and transformed into well-known risks by the acquisition and exploitation of knowledge (Janszen, 2000).

In this section of the study the generic processes are discussed, with an explanation of how they convert their specific inputs to specific outputs. By using these processes the organisation is able to create scenarios of possible business situations. Many researchers in the field of scenarios have made generalized remarks concerning the topic (Masini \& Vasquez, 2003; Amit \& Schoemaker, 1993):

i. Scenarios are drawn from various personal experiences and perspectives;

ii. Scenarios have multidisciplinary and multidimensional characteristics;

iii. They help organizations and individuals to develop and broaden mental maps of possible future realities;

iv. They understand the fundamental drivers of business, market and technological trends and changes; and

v. Promote a process of strategic thinking and organizational knowledge creation through learning (Grant, 2003; Chermark, 2003)

These processes are:

1. Generation of ideas

2. Management and decision making

3. Prototyping

4. Knowledge generation, acquisition and exploitation

5. Intra- and extra-organizational implementation

6. Teambuilding

Although all these processes are equally important and not executed in any specific sequence, depending on the stage of the development phase, one process will be more dominant than the others. Teambuilding will always be seen as the always present and mediating process.

These processes and their interaction are described in Figure 2 the Innovative Feedback Loop: 


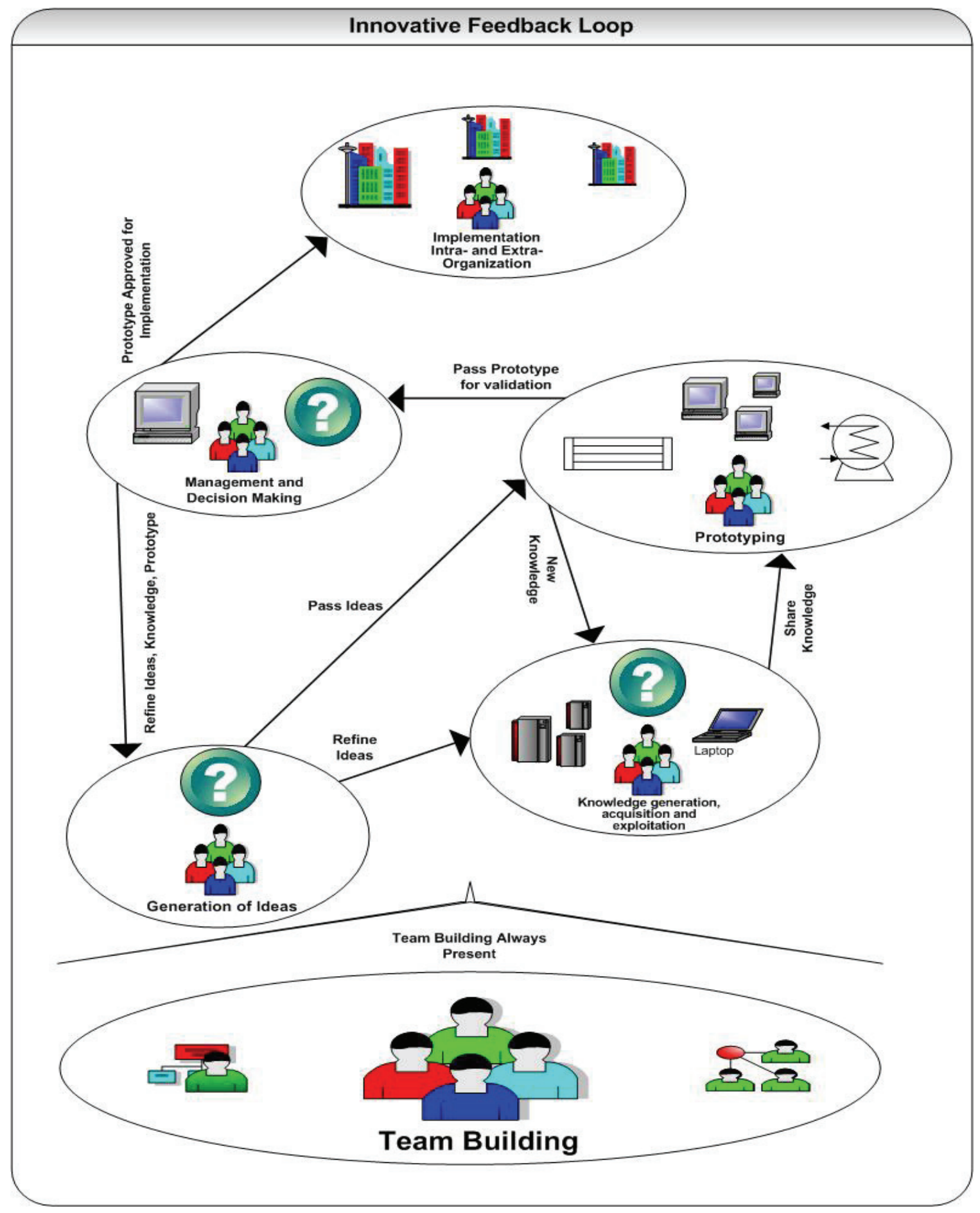

Figure 2: Innovative Feedback Loop

\section{The conceptual framework for modeling business capabilities}

The conceptual framework is an essential reference point from which the construction of business capabilities takes place. Table 2 is a representation of the framework, followed by a description. 
Table 2: The conceptual framework for the modeling of business capabilities

\begin{tabular}{|c|c|c|c|c|c|c|}
\hline \multicolumn{7}{|c|}{ The Conceptual Framework for Modeling Business Capabilities } \\
\hline & $\begin{array}{l}\text { Elements } \\
\text { of } \\
\text { Guidance }\end{array}$ & $\begin{array}{l}\text { Business } \\
\text { Processes }\end{array}$ & Resources & Technology & People & Objects \\
\hline $\begin{array}{c}\text { Extemal } \\
\text { Environmental } \\
\text { Knowedge }\end{array}$ & & & & & & $\begin{array}{l}\text { Industry Foresight and } \\
\text { Customer Insight }\end{array}$ \\
\hline Ends & & & & & & $\begin{array}{l}\text { Vision, Goals and } \\
\text { Objectives }\end{array}$ \\
\hline $\begin{array}{c}\text { Internal } \\
\text { E nvironmental } \\
\text { Knowledge }\end{array}$ & & & & & & \begin{tabular}{|l|} 
Entity-Relationship \\
Diagrams, Functional \\
Decomposition \\
Diagrams, Flow Charts, \\
Prototypes \\
(Organizational \\
Learning)
\end{tabular} \\
\hline Means & & & & & & $\begin{array}{l}\text { Mission, Strategy and } \\
\text { Tactics }\end{array}$ \\
\hline
\end{tabular}

The framework consists of perspectives as rows and abstractions as columns. Each of the abstractions can be found in one of the perspectives. Some abstractions might be duplicated in the perspectives, but because of the perspective change the abstraction will have a different scope or purpose. Business processes, for instance, are found in the means perspective and assists towards executing missions, strategies or tactics. This same abstraction is found in ends. The business process as abstraction has the same properties but here it serves a different purpose in that it helps accomplish a vision, goal or objective.

\section{Capability construction feedback loop}

This feedback loop consists of five interacting sections or parts that work collaboratively and enable an agile organisation. A description of the five parts follows:

i. Object Inventory

A repository is kept of all the information abstracts of the organization. These objects store complex information like the company's strategic plan and even small business entities like customer or order information. These objects could then be compiled in to usable bits that make sense to the organization to essentially form new objects. These objects and combinations of them are then sent to the innovative feedback loop for refinement. 


\section{ii. Innovative Feedback loop}

Objects are received in this loop for testing and refinement. Within this feedback loop the innovative feedback loop operates on its own and produces, refines and stores knowledge, analyses the internal environment (organisation) and the external environment (industry and customers), and constructs components or capabilities by utilizing the object inventory. Here the seven generic new product and new business development processes are used to produce prototypes or components. These prototypes or components produce new knowledge while tested. When ready they are implemented in the organization. Once again knowledge about them are gained and stored in the knowledge repository.

\section{iii. Knowledge repository}

This repository receives information from the innovative feedback loop, from organizational analysis and from the constructed capabilities. There are four major functions to create and store new knowledge. Customer Insight and Industry Foresight are two very specific research practices focusing on the customer the service or product is intended for and the industry within which the organization operates.

\section{iv. Organizational Analysis}

As the organization produce products and supply services the organization is continuously monitored. All the knowledge whether positive or negative are send back to the knowledge repository and the components are refined or replaced.

\section{v. Constructed Capabilities}

Here a repository of possible business capabilities resides. They enable the organization to be agile. This essentially entails that the organization can use which ever stored business capability to react to a specific business situation instantaneously.

The Capability construction feedback loop is depicted in Figure 3. 


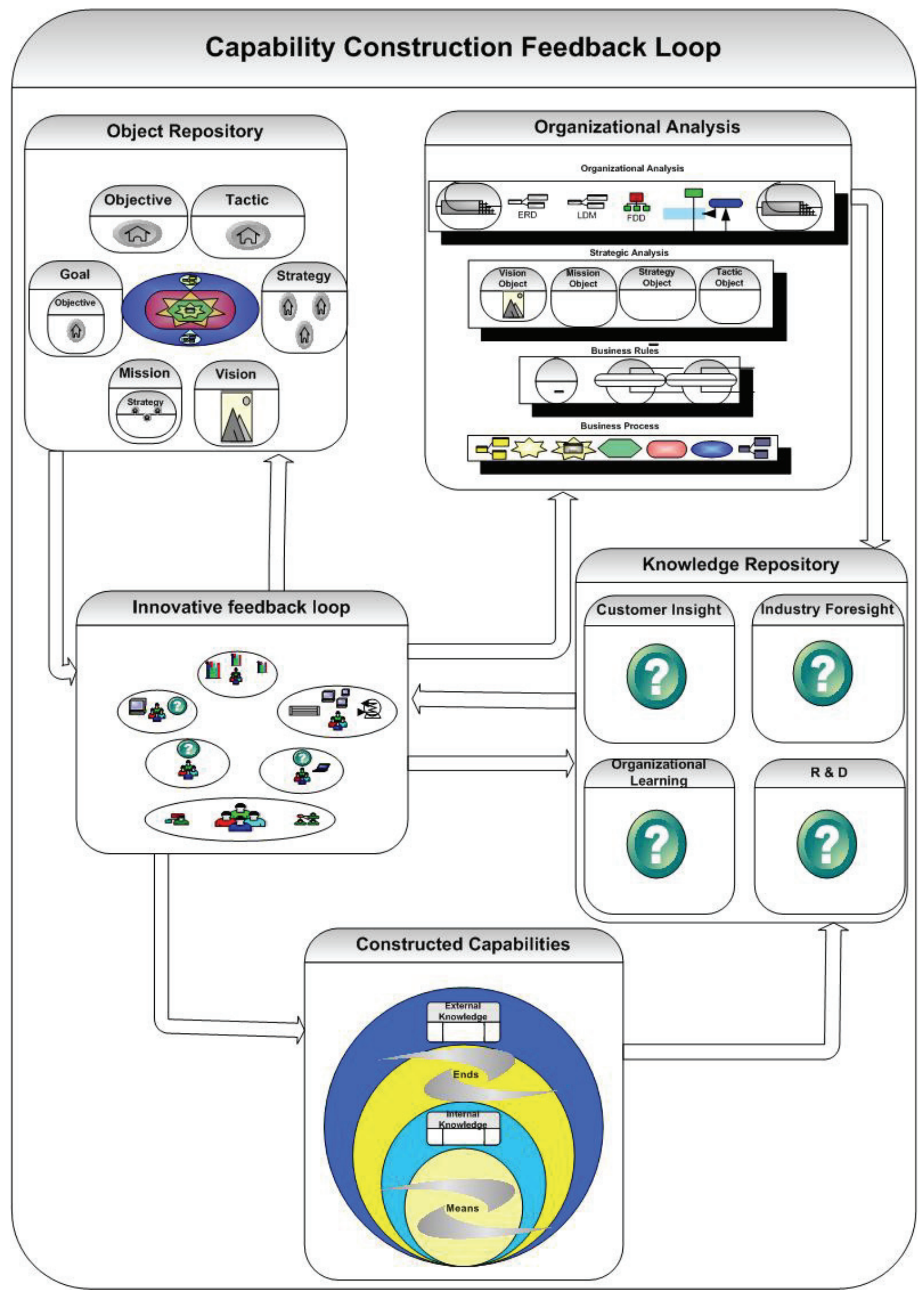

Figure 3: The capability construction feedback loop 


\section{Capability construction feedback loop}

The capability construction feedback loop is an ongoing process that continuously refines and constructs business capabilities. Figure 4 is a representation of the capabilities constructed.

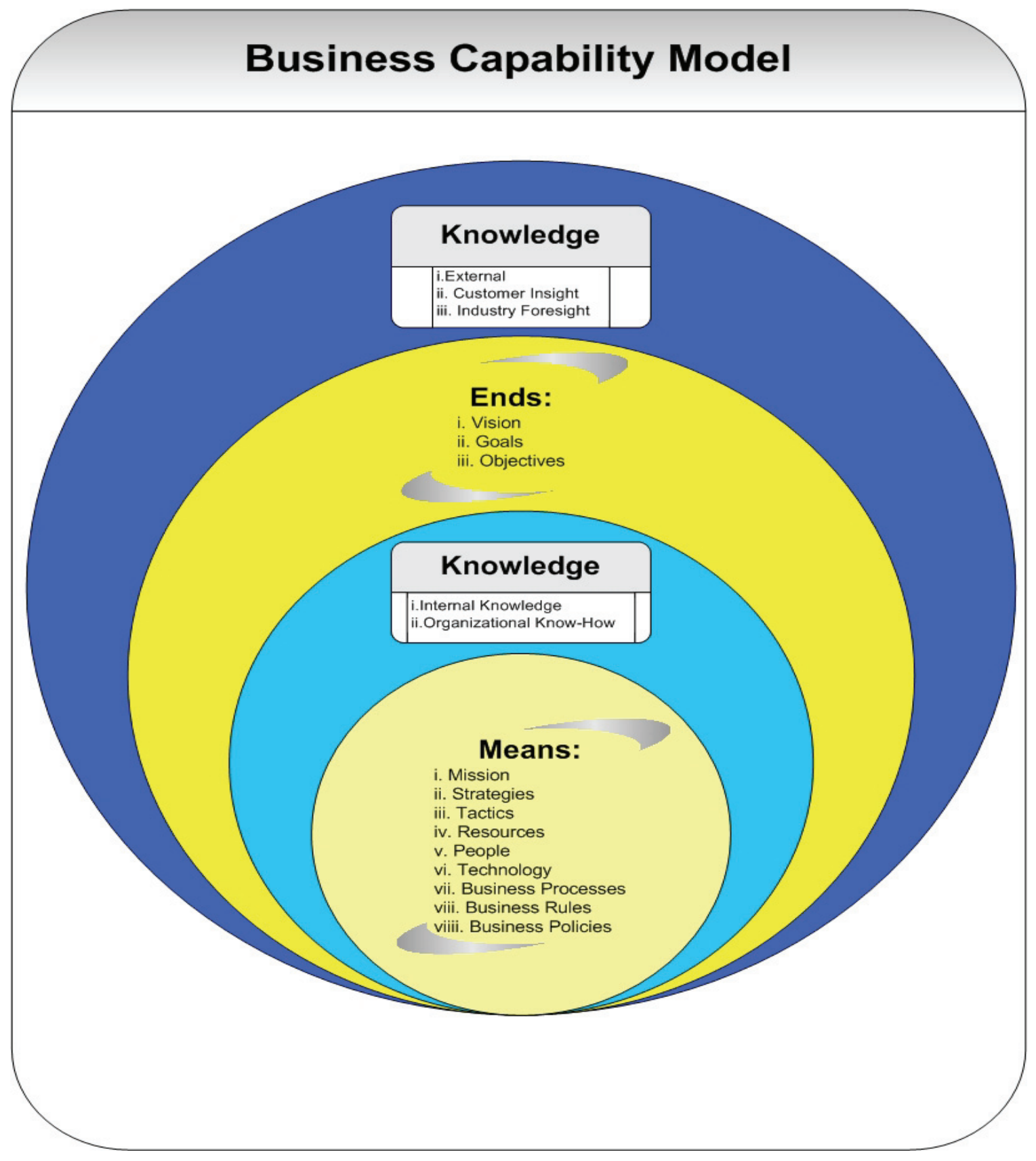

Figure 4: The business capability model

\section{Research Methodology}

This study that was done was divided into five phases, set out in Table 3. Although all of these phases are not explicitly covered in this article it provides a background of the research conducted. 
Table 3: Five phases of the research done.

\begin{tabular}{|c|c|}
\hline \multicolumn{2}{|r|}{ Research Phases } \\
\hline Phase One & Literature Review \\
\hline $\begin{array}{l}\text { Research } \\
\text { Methodology }\end{array}$ & Content Analysis and Qualitative Research \\
\hline Phase Two & Business Capability Description and Organizational Context \\
\hline $\begin{array}{l}\text { Research } \\
\text { Methodology }\end{array}$ & Content Analysis and Qualitative Research \\
\hline Phase Three & Organizational Analysis \\
\hline $\begin{array}{l}\text { Research } \\
\text { Methodology }\end{array}$ & Content Analysis and Qualitative Research \\
\hline Phase Four & Organizational Modeling \\
\hline $\begin{array}{l}\text { Research } \\
\text { Methodology }\end{array}$ & Content Analysis and Qualitative Research and a Systems approach \\
\hline Phase Five & Business Capability Construction \\
\hline $\begin{array}{l}\text { Research } \\
\text { Methodology }\end{array}$ & Model and Systems Approach \\
\hline
\end{tabular}

The first phase is the literature review, describing the need for a conceptual framework for modeling business capabilities. Describing business capabilities and their organizational context is the focus of phase two. The third phase illustrates how to analyze an organisation towards acquiring knowledge of both the internal and external environment. Phase four deals with encapsulating and making sense of all the information acquired during the analysis phase. The fifth phase focuses on the construction of building business capabilities and essentially producing a model.

The types of research used in the study and how they relate to the various phases of the study are discussed in this section. Each type contributes uniquely to the mix of research approaches needed to successfully produce a conceptual framework for modeling business capabilities. The types of research used are content analysis and qualitative research, combined with a systems approach to assist in the development of a model.

\section{Implications of the Study}

This study introduced a formalized approach towards linking strategic thinking and innovation to operations and information modeling. This approach fits like a glove with one of the latest trends in Information Technology called Service Oriented Architecture. The strength in this approach lies in the strong focus on analysis, abstraction and methodology. Abstractions in information, knowledge, process and business rules and the conceptual methodology in recompiling them into useful encapsulations for analysis purposes or further compilation towards business capabilities based on analysis. 
This study contributed greatly towards defining a methodology for supporting an agile organization: an organization that extracts and utilizes knowledge and adapts physically to adhere to changes in the environment, whether internally or externally.

\section{Opportunities for Further Research}

When developing models, prototyping, testing and refinement is essential to the validity of the model. This study has many interacting parts and thus produced very complex models and submodels (models interacting within others). Complex models were developed as a result of the conceptual framework's nature. Further research should be done on all the conceptual parts and how they could be successfully integrated to effectively construct, test and refine business capabilities.

\section{Conclusion}

It is clear that organizations face times that they have never faced before and the bad news is even more uncertain and dynamic times lie ahead. What is needed is an agile organization: agile in architecture, strategy, process, innovation and implementation. This study made a significant contribution with its approach to business capabilities. It produced a conceptual view of organizational analysis, business capability framework and construction of business capabilities.

The four major outcomes of this study is the business capability model, business capability framework, innovative feedback loop and the organizational feedback loop.

\section{References}

1000Ventures. (2006). The basic building bock of your firm and the basis of your competitive advantage. Organizational capabilities. Retrieved from: http://www.1000ventures.com/business_guide/crosscuttings/capabilities_corporate.html

Amit, R. \& Schoemaker, P.J.H. (1993). Strategic assets and organizational rent. Strategic Management Journal, 14(1), 33-46.

Bowman, E. H. \& Moskowitz, G. T. (2001). Real options analysis and strategic decision making. Organization Science, 12(6), 772-777.

Bowman, E. H., \& Hurry, D. (1993). Strategy through the option lens: An integrated view of resource investments and the incremental-choice process. Academy of Management Review, 18(4), 760-782.

Business Rule Group. (2000a). (Online). Business rules - The standard model for business rule motivation. Retrieved from: http://www.businessrulesgroup.org

Business Rule Group. (2000b). (Online). Business rules - What are they? Retrieved 25 August, 2005 from: http://www.businessrulesgroup.org

Bredemeyer Consulting. (2003). Enterprise architecture as business capabilities architecture. Available from: http://www.bredemeyer.com/pdf files/Presentations/EnterpriseArchitectureAs - CapabilitiesArchSlides.PDF

Bryans, P. \& Smith, R. (2000). Beyond training: Reconceptualising learning at work. Journal of Workplace Learning, 12(6), 228-235.

Chermark, T.J., \& Van Der Merwe, L. (2003). The role of constructivist learning in scenario planning. Futures, 35, 445-460.

Coyle, D. (1999). The weightless world: Thriving in the digital age. Oxford: Capstone Publishing Limited.

Eisenhardt, K.M., \& Martin, J.A. (2000). Dynamic capabilities: what are they? Strategic Management Journal, 21(special issue), 1105-1121. 
Grant, R.M. (1996a). Toward a knowledge-based theory of the firm. Strategic Management Journal, 17(Winter, special issue), 109-122.

Grant, R.M. (1996b). Prospering in dynamically-competitive environments: organizational capability as knowledge integration. Organization Science, 7, 375-387.

Grant, R.M. (2003). Strategic planning in a turbulent environment: Evidence from the oil majors. Strategic Management Journal, 24, 491-517.

Gulati, R., (1998). Alliances and networks. Strategic Management Journal, 19(4), 293-317.

Hamel, G. \& Prahalad, C.K. (1994). Competing for the future. Harvard Business School Press.

Harrison, B. (1996). The importance of being complementary. Technology Review, 99(7 October), 65.

Hubbard, G., Pocknee, G. \& Taylor, G.A. (1997). Practical Australian strategy. Sydney: Prentice-Hall.

Innovation Point. (2004). (Online). Customer insight as a driver of strategic innovation. Retreived from: www.innovation-point.com

Janszen, F. (2000). The age of innovation. London: Prentice Hall.

Kardasis, P. \& Loucopoulos, P. (2005). A roadmap for the elicitation of business rules in information systems projects. Business Process Management Journal, 11(4), 316-348. Emerald Group Publishing.

Kelly, K. (1998). New rules for the new economy. London: Penguin Putnam.

King, W.R. (1995). Creating a strategic capabilities architecture. Information Systems Management, 12(1), 67-69.

Kogut, B., \& Kulatilaka, N. (2001). Capabilities as real options. Organization Science, 12(6), 744-758.

Loasby, B.J. (1998). The organisation of capabilities. Journal of Economics.

Makadok, R. (2001). Toward a synthesis of the resource-based and dynamic-capability views of rent creation. Strategic Management Journal, 23(5), 387-401.

Masini, E., \& Vasquez, J. (2003). Scenarios as seen from a human and social perspective. Technological Forecasting and Social Change, 65, 49-66.

Lei, D., Hitt, M.A. \& Bettis, R. (1996). Dynamic core competences through meta-learning and strategic context. Journal of Management, 22, 549-569.

Malhotra, Y. (1996). Enterprise architecture: An overview. Brint Institute. Retrieved from: http://www.kmbook.com/enterarch.htm

NetMBA. (2005). Value chain analysis. Retrieved 11 January 2006 from: http://www.netmba.com/strategy/value-chain/

Norman, P. (2005). Evaluation of an information system and development of time saving extensions to its functionality. Leeds University. Retrieved from: http://www.engineering.leeds.ac.uk/comp/pg/documents/norman.pdf

Pandza, K., Horsburgh, S., Gorton, K. \& Polajnar. (2003). A real options approach to managing resources and capabilities. Retrieved from:

http://emeraldinsight.com/Insight/ViewContentServlet?Filename=/published/emeraldfulltextarticle/pdf 10240230905.pdf

Pastore, R. (1995). Competing interests: An interview with Michael E. Porter. CIO, 9, (October 1), 63-68.

Penrose, E.T. (1959). The theory of the growth of the firm. New York, NY Wiley.

Pearce, J.A. \& Robinson, R.B. (2000). Strategic management, formulation, implementation and control (7th ed.). Boston: Irwin, McGraw-Hill.

Pohl, K. (1993). The three dimensions of requirements engineering. In Proceedings of the 5th International Advanced Information Systems Engineering 1993, Paris, Springer, Berlin, pp. 275-292. 
Robson, W. (1997). Strategic management and information systems ( $2^{\text {nd }}$ ed.).

Ross, R. (1994). The business rule book: Classifying and modelling rules. Database Research Group Inc.

Rumelt, R.P., Schendel, D.E., \& Teece, D.J. (1991). Strategic management and economics. Strategic Management Journal, 12 (Winter, special issue), 5-29.

Simon, K. A. (2000). Business processes and IT in the pharmaceutical industry. Department of Informatics, School of Economics and Commercial Law, Göteborg University, Sweden. Retrieved from: http://www.handels.gu.se/epc/archive/00002874/01/simon.pdf

Spender, J.C. (1996). Making knowledge the basis of a dynamic theory of the firm. Strategic Management Journal,17 (Winter, special issue), 45-62.

Thompson, A. A. Jr., Strickland III, A. J. \& Gamble, J. E. (2005). Crafting and executing strategy. McGraw Hill / Irwin.

Tregoe, B. \& Zimmerman, J. (1980). Top management strategy. Simon \& Schuster Adult Publishing Group.

Tutor. (2004). Retreived from: www.tutor.net

Von Halle, B. (2000). The art of letting go. Database Programming and Design. Retrieved from: www.dbpd.com/vault/9702arch.htm

Whitten J.L. \& Bently L.D. (2001). Systems analysis and design techniques ( $5^{\text {th }}$ ed.). New York: Irwin/McGraw-Hill.

Zachmann, J. (1998). The framework for enterprise architecture and the search for the owners view of the organization. Retrieved from: http://www.zifa.com

\section{Biographies}

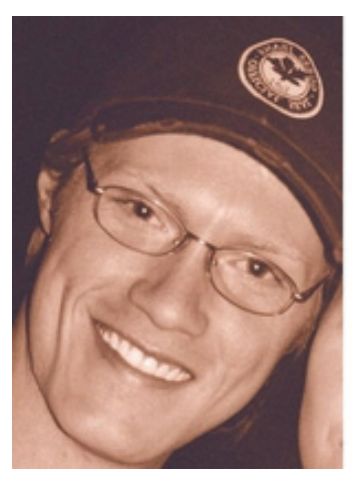

Jean-Pierre Brits has been studying at the Tshwane University of Technology since 2000 and finished a Masters degree at the end of 2006. He has been developing software for the past 4 years but has changed his focus to project management, service analysis and the study of business capabilities. He has started a business, called Business Capability Consulting, that focus on further research on business capabilities, and are looking for alliances and collaborations. The aim of this business is to develop a knowledge base in the field of business capabilities. This knowledge base will serve as source to an annual textbook, courses and consulting services in the field of business capabilities.

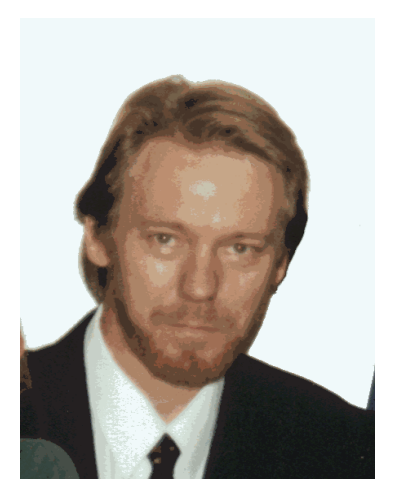

Gerrit Botha is an independent consultant practicing the art and science of enterprise and IT strategy and architecture. He promotes the concept of business capabilities and has successfully developed and implemented several strategies in the public and private sectors, using such an approach.

He lectures on the masters program of the Tshwane University of Technology and has published several articles and conference proceedings on the subject of "value innovation" which is also referenced internationally. 


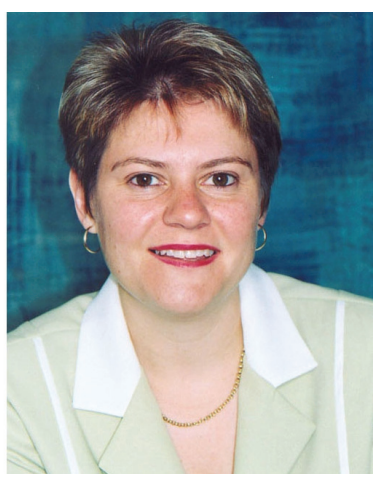

Prof Marlien Herselman is an Associate Research Professor of the Faculty of Information and Communication Technology. In this capacity she assists lecturers and postgraduate students in research projects, National Research Foundation (NRF) projects, in writing research articles, and in other research-related activities. She obtained her PhD at the University of Pretoria in 1999. Her PhD studies focused on the use of computer games. She is currently busy with research on Technology assessment in rural communities regarding ehealth in South Africa with a National Research Foundation funded project.

She was also chairperson of the Faculty Quality Implementation Team from 2003 to 2005. In 2005 she received the prize as Women Researcher of the Year 2004 at Tshwane University of Technology. 